\title{
PRAYER ROOM QIBLA DIRECTION AT SCHOOL IN BUKITTINGGI : (Qibla Study in Junior High School and Senior High Schools Prayer Room)
}

Hendri

Institut Agama Islam Negeri Bukittinggi

hendridatuak7@gmail.com

\section{Abstract}

Facing the qibla is one of the legal requirements in conducting prayer. The existence of the prayer room as a place of prayer in the school aims to fulfill the worship need for Muslim students and teachers, especially the midday prayer. However, the school owner never concerns towards qibla direction in School prayer room. This paper answers how the accuracy of the direction of the center of prayer at junior high school and senior high school in Bukittingg. By using library research method, researcher found that the method used is estimation method with concerning on Sunset direction, concerning on the buildings around it which defined in falak field as taqribi method. Furthermore, schools owners also used astronomy theory as the qibla direction method determination, such as compass qibla, Sun shadow and theodolite. Regarding to the qibla direction accuracy in Senior high schools and Junior high schools in Bukittinggi, researcher found there were two schools which were in accurate qibla direction, two schools which can be tolerated and eight remaining prayer rooms which were unforgivable due to incorrect method while implementing to decide the qibla direction.

Keywords: Qibla; Prayer Room; Schools

\section{Abstrak}

Menghadap kiblat merupakan salah satu syarat sahnya shalat. Kehadiran musholla sebagai tempat solat disekolah bertujuan memenuhi kebutuhan beribadah bagi siswa dan guru yang muslim, terkhusus solat siang. Namun pemilik sekolah tidak pernah peduli terhadap arah kiblat di mushala sekolah tersebut. Tulisan ini menjawab bagaimana keakuratan arah kiblat mushala di sekolah menengah tingkat pertama dan sekolah menengah atas se kota Bukittinggi. Dengan memakai metodhe penelitian field research, Peneliti menemukan bahwa metode yang pemilik sekolah gunakan dalam menentukan arah kiblat yaitu menggunakan metode yang berdasarkan perkiraan saja, dengan berpatokan kepada arah matahari terbenam, berpatokan kepada bangunan di sekitar yang disebut dalam ilmu falak metode taqribi. Selain itu pemilik sekolah juga menggunakan teori astronomi dalam metode penentuan arah kiblat, seperti kompas kiblat, bayang-bayang Matahari dan theodolite. Terkait dengan itu akurasi arah kiblat mushala pada sekolah menengah atas dan sekolah menengah pertama se-kota Bukittinggi, berdasarkan hasil penelitian terdapat 2 prayer room yang arah kiblatnya 
menghadap kiblat, 2 mushala yang arah kiblatnya kategori batas toleransi serta terdapat 8 mushala yang arah kiblatnya diluar batas toleransi karena metode yang kurang tepat ketika menentukan arah kiblat.

Kata kuci : Kiblat; Musholla; Sekolah

\section{A. Introduction}

Kaaba is the holiest place in Islam that was built by Prophet Ibrahim with his son Prophet Ismail where Arabian is generally respect this holy place. Every year in the Hajj month, the Arabian from all over visit Mecca as a religious obligation. Prophet Muhammad SAW when born even brought by his grandfather Abdul Mutthalib to the foot of the Kaaba and in the holy place that is the baby of the Quraiys tribe ${ }^{1}$. They are truly proud of the Ka'bah and even devote themselves to taking care of it. They keep idols around the Kaaba and make the Kaaba the center of ritual activities. They have a believe that the idols are friends of God.

The obligation to pray at first is not simultaneously accompanied by the obligation to face the Qibla. The Prophet Muhammad (as ijtihad) performed the obligation to pray by facing the Baitul Maqdis in Yarussalem Palestine. ${ }^{2}$

Along with the progress and development time by time, many places have provide prayer rooms, one of them is in Senior high school and junior high school, especially in Bukittinggi. Prayer rooms in the school are provided to increase the worship of students and all residents in schools. The school is an educational place, so the school certainly prioritizes buildings for learning, however prayer room also has been priority as an additional building in schools. Then, this commonly happens that the stakeholders are lack of attention toward Prayer room Qibla direction. Sometimes the stakeholders only trusts the direction of the prayer room's building around the school as the trustworthy direction.

Based on preliminary research conducted at junior high school 4 Bukittinggi, it was found that qibla direction of prayer room had a deviation amoung $14^{\circ}$. Surely, this

\footnotetext{
${ }^{1}$ Ahmad Izzuddin, Kajian Terhadap Metode-Metode Penentuan Arah Kiblat Dan Akurasinya (Kementerian Agama Republik Indonesia, 2012).

${ }^{2}$ Ahmad Izzuddin, Kajian Terhadap Metode-Metode Penentuan Arah Kiblat Dan Akurasinya (Kementerian Agama Republik Indonesia, 2012).
} 
is an unexpected willingness. Nobody aims to guarantee the worship that has been done by the people in the Prayer room.

\section{B. Research Method}

Based on the reason above, the researcher was interested to conduct a survey of the prayer room in the junior high school and senior high school in Bukittinggi. This research is intended to measure the accuracy of the qibla direction and see the deviation to be used as a guide for schools to improve qibla direction. This research using field research to check the accuracy of prayer room qibla in daily reality.

\section{Discussion}

The word al-qiblah is repeated 4 times in Al-Qu'ran ${ }^{3}$. The word in terms of language is taken from the root word qabala-yaqbalu which means 'facing'. According to $K B B I$ (Indonesian dictionary), it means the qibla 'direction to the Kaaba in Mecca (at the time of prayer $)^{4}$ besides, in the Al-Munawwir dictionary the Kaaba is interpreted as the Kaaba. ${ }^{5}$ In contrast, in the encyclopedia of Islamic Law the Ka'bah is defined as the building of the Ka'bah or the direction that Muslims go towards in carrying out some of the worship ${ }^{6}$

All of Muslims are required to know the prayer time and the direction to praying in order to do 5-time praying times. ${ }^{7}$ The first long distance travel for the majority of Indonesian Muslims is usually obtained when performing the pilgrimage, Nowadays, determining Qibla direction is not a difficult thing, ${ }^{8}$ because there are many tools that

\footnotetext{
${ }^{3}$ Reza Akbar, "Sejarah Perkembangan Ilmu Falak Dalam Peradaban India Dan Keterkaitannya Dengan Islam," Jurnal Ilmiah Islam Futura 17 (2017): 50-72.

${ }^{4}$ Suci Novira Aditiani, Dyah Fitriana Masithoh, and Nonoh Siti Aminah, "Penentuan Arah Kiblat Dengan Metode Segitiga Bola," in Prosiding: Seminar Nasional Fisika Dan Pendidikan Fisika, vol. 6, 2015.

${ }^{5}$ Fahmi Fatwa Rosyadi Satria Hamdani, Ramdan Fawzi, and Rifki Gapuraning Syahid, "Pendampingan Pengukuran Arah Kiblat Masjid Di Rancabango Garut," Dimas: Jurnal Pemikiran Agama Untuk Pemberdayaan 18, no. 1 (2018): 19-34.

${ }^{6}$ Endro Adiwirawan, "Relasi Spasial Antara Kegiatan Ritual Ibadah Berjamaah Dengan Arsitektur Mesjid Di Bandung Studi Kasus: Masjid Cipaganti, Masjid Salman, Dan Masjid Al Irsyad," Idealog: Ide Dan Dialog Desain Indonesia 2, no. 1 (2017): 1-19.

${ }^{7}$ Izzuddin, Kajian Terhadap Metode-Metode Penentuan Arah Kiblat Dan Akurasinya.

${ }^{8}$ Susiknan Azhari, "Perkembangan Kajian Astronomi Islam Di Alam Melayu," Jurnal Figh 7 (2010): $167-184$.
} 
can be used as a reference in determining Qibla direction that can be obtained by buying individuals, and even many also prayer mats that was completed with Qibla direction indicators 9

Facing the qibla direction basically in fiqh discourse is a valid condition of the prayer which cannot be offered, except in some cases. First, for those who are in fear, forced situations, seriousl ill conditions are not allowed to face the qibla at prayer time. This is based on Qs. Al-Baqarah verse 239. ${ }^{10}$ Second, those who pray the sunnah on a vehicle based on the hadith which is narrated by Bukhari ${ }^{11}$ from Jabir bin Abdullah and also according to Imam Muslim, Tarmidzi and Ahmad which states that the Prophet Muhammad SAW performed sunnah prayers on his vehicle when in journey from Mecca to Medina. At that time the word of Allah SWT : ${ }^{12}$

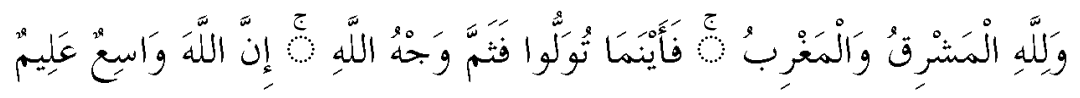

Meaning: and Allah belongs east and west, So wherever you face there is the face of God [83]. Indeed, Allah is vast (His mercy) and All-knowing

That is where the face of Allah means; God's power covers all of nature; therefore wherever man is, God knows his deeds, because he is always dealing with God. ${ }^{13}$

In this case, the author wants to distinguish the extent of the nature of ijtihad recognizing qibla direction by linking the areas of normavity and historicity, the process, the process of calculation according to various theories at once will be explained as already alluded to in the previous explanation. The Kaaba, the temple of

\footnotetext{
${ }^{9}$ Susiknan Azhari, "Perkembangan Kajian Astronomi Islam Di Alam Melayu,” Jurnal Fiqh 7 (2010): $167-184$.

${ }^{10}$ Nur Hidayatullah el-Banjary, "Menentukan Arah Kiblat Dengan Hembusan Angin (Perspektif Fiqh Dan Sains)," Al-Marshad: Jurnal Astronomi Islam Dan Ilmu-Ilmu Berkaitan 2, no. 1 (2017).

${ }^{11}$ Fenty Windy Anurkarina, "Perilaku Tokoh KH. Ahmad Dahlan Dalam Novel Sang Pencerah Karya Akmal Nasery Basral,” KEMBARA: Jurnal Keilmuan Bahasa, Sastra, Dan Pengajarannya 1, no. 1 (2015): 34-42.

${ }^{12}$ Muhyiddin Khazin, “Cara Mudah Mengukur Arah Kiblat, Cet. II,” Yogyakarta: Buana Pustaka, 2006.

${ }^{13}$ Hosen Hosen and Ghafiruddin Ghafiruddin, "Akurasi Arah Kiblat Masjid Di Wilayah Kecamatan Pademawu Kabupaten Pamekasan Dengan Metode Mizwala Qibla Finder,” Al-Ihkam: Jurnal Hukum Eु Pranata Sosial 13, no. 2 (2018): 364-381.
} 
Allah, the qibla and center of various Muslim worship services are sacred buildings located in Mecca. The Dictionary of Islam explains that the Kaaba (Baitul Makmur) was firstly built two thousand years before the creation of the world. ${ }^{14}$

The Prophet existed, regarded as the foundation laying on the building of the Kaaba on earth. The stones used as Ka'bah buildings were taken from the five sacred mountains, namely Sinai, Al-Judi, Hira, Oliver and Lebanon. ${ }^{15}$

\section{C.1. Theoritical Review}

Qibla direction measurement methods that are popular as well as those developed in recent years there are 6 kinds $^{16}$, namely 1) qibla measurement using a compass $^{17}$; 2) Qibla measurement using a istiwa' instrument by utilizing the sun's shadow; 3) measuring qibla direction using the global rashd al-qiblah method; 4) measuring qibla direction using the local rashd al-qiblah method; 5) Qibla direction measurement using theodolite and 6) Qibla direction measurement using azimuth from Maharati shadows at any time ${ }^{18}$

In this study the author uses the Qibla compass, Qibla direction application, the sun's shadow on the Qibla rasydul and theodolite because at present it is the best method including being able to know precision up to the second because theodolite has a sensitive digital scale, compared to other measurements such as compasses the average level of accuracy is only up to degrees ${ }^{19}$

\section{C.2. Research Findings}

In order to have capability to describe the accuracy of qibla direction toward prayer room in senior high schools and junior high schools in Bukittinggi,

\footnotetext{
${ }^{14}$ Moedji Raharto and Dede Jaenal Arifin, "Telaah Penentuan Arah Kiblat Dengan Perhitungan Trigonometri Bola Dan Bayang-Bayang Gnomon Oleh Matahari,” Jurnal Fisika Himpunan Fisika Indonesia 11, no. 1 (2011): 23-29. Islam.”

${ }^{15}$ Akbar, "Sejarah Perkembangan Ilmu Falak Dalam Peradaban India Dan Keterkaitannya Dengan

${ }^{16}$ Muhammad Adieb and Muhammad Adieb, "Hukum Penentuan Arah Kiblat Perspektif Madzhab Syafi'i Dan Astronomis," Inklusif (Jurnal Pengkajian Penelitian Ekonomi Dan Hukum Islam) 4, no. 1 (2019): 33-46.

${ }^{17}$ Muhammad Nurkhanif, "Problematika Sosio-Historis Arah Kiblat Masjid 'Wali' Baiturrahim Gambiran Kabupaten Pati Jawa Tengah," Al Qodiri: Jurnal Pendidikan, Sosial Dan Keagamaan 15, no. 2 (2018): 32-58.

${ }^{18}$ Agus Yusrun Nafi, "Verifikasi Fatwa MUI Nomor 03 Tahun 2010 Tentang Arah Kiblat," Mahkamah: Jurnal Kajian Hukum Islam 9, no. 1 (2016).

${ }^{19}$ Sayful Mujab, "Qiblat Tiap Saat Sebagai Jembatan Penentu Arah Qiblat," Yudisia: Jurnal Pemikiran Hukum Dan Hukum Islam 6, no. 1 (2016): 160-180.
} 
researchers explained the identity and history of the construction of the prayer rooms in senior high school and junior high school in Bukittinggi firstly, then the accuracy of qibla direction and the solutions which was made when there was a mismatching in the qibla direction and conclusions are given.

There are 12 scattered prayer room that will be studied. 5 in high schools and 7 in junior high schools in Bukittinggi. The measurement mechanism and precision analysis of qibla direction in senior high schools and junior high schools in Bukittinggi are exemplified as follows:

a. Profile of Prayer Room in Senior High School 1 Bukittinggi

Al-Akram Prayer room is located in front of the school, and can accommodate up to 500 people. Besides being used for religious activities of school residents, the prayer room is also opened to the general public who want to carry out worship.

Al Akram Prayer room was built in 2003 to 2004, and almost all costs in the construction of this prayer room were borne by the alumni of SMA 1 Bukittinggi, the alumni of Bukittinggi 1 high school were equally committed in establishing the prayer room, starting from the design process to the inauguration by the mayor of Bukittinggi, Mr. H. Djufri. Before making a prayer room construction plan, Qibla direction was determined by experts from the Ministry of Religion in Bukittinggi ${ }^{20}$

b. Profile of Prayer Room in Senior High School 2 Bukittinggi

The Prayer room in Senior high school 2 Bukittinggi is located on the second floor of a school building which is on the first floor there is a classroom. This prayer room was built in 2003. In 2017 a prayer room wall was painted, and in 2018 the prayer room floor began to be tiled. Previously in the 90s, prayer room in SHS 2 Bukittinggi was located on the first floor, but its use was only for teachers. Prayer room in SHS 2 Bukittinggi has an area of $16 \mathrm{~m} \times 7 \mathrm{~m}$ and can only accommodate 60 worshipers or two classes, so that other students

\footnotetext{
${ }^{20}$ Interview with room prayer responsible, Ust. Afrizal,on Friday at $25^{\text {th }}$ January 2019
} 
perform dzuhur praying in the sports field by leading to the Qibla as expecting or seeing the prayer room building around, but when it is raining students of SMA Negeri 2 Bukittinggi pray at the class. It is not known exactly who measures Qibla direction in this prayer room, because it has been very long, and qibla direction has also never been corrected $^{21}$.

c. Profile of Prayer Room Senior High School 3 Bukittinggi

Bābu at-taubah prayer room is located in the front side of the entire school building and is adjacent to the old prayer room which is not used to pray. In its construction, Bābu at-taubah prayer room was divided into two stages. In the first stage, the prayer room was built by the government. However it was not finished yet and was neglected due to insufficient funding so that the development process had to be temporarily stopped. After several years of neglect, with the initiative of alumni to continue development, the construction of the prayer room was continued by using funds collected by alumni so that the construction of the prayer room was continued until finished and used until now. ${ }^{22}$ Headmaster of the school does not know in detail who determines the qibla direction of the prayer room because the prayer room was built initially by the government and the school only provided the location.

\section{d. Profile of Prayer Room Senior High School 4 Bukittinggi}

Mukhlisin Prayer room is located near the sports field and next to the classroom. With a small size of building, this prayer room is estimated to hold up to 100 people. Mukhlisin prayer room was built in 2000 and in that year the

\footnotetext{
${ }^{21}$ Interview with teacher ofn SMA Negeri 2 Bukittinggi, Riri Kurniaty,on Wednesday at $30^{\text {th }}$ January 2019D. Prayer room High School 4 Bukittinggi

Mukhlisin prayer room is located near the sports field and next to the classroom. With a size that is not too large, this mushalla is estimated to hold up to 100 people.

Mukhlisin prayer room was built in 2000 and in that year the construction was still continuing, because to complete the construction of the prayer room there were several stages. This is due to the insufficient funds for building prayer room from the government and the school must seek additional funds such as collecting student infaq money, student guardian fees and donations from surrounding sidents.

${ }^{22}$ Interview with teacher of SMAN 3 Bukittinggi, Ms Fitria Lisa, on Wednesday at $23^{\text {rd }}$ January 2019
} 
construction was still continuing, because to complete the construction of the prayer room there were several stages. This is due to the insufficient funds for building prayer room from the government and the school must seek additional funds such as collecting student donation, student guardian fees and donations from surrounding residents.

e. Profile of Prayer Room Senior High school 5 Bukittinggi

The construction of the prayer room is in line with the construction of the school building so it is unknown who built it and who determined the qibla direction of the prayer room. According to one teacher, said that the prayer room had been in such a position from the past and that the prayer room builder. So the one who determined the qibla direction at that time was a builder. $^{23}$

f. Profile of Prayer Room in Junior High School 1 Bukittinggi

Prayer room of junior high school 1 Bukittinggi is located on the side of the school building. The prayer room at junior high school 1 Bukittinggi was established in 2007. At the time of the construction of it's prayer room, the school determined Qibla direction based on the surrounding buildings, but after some time, measurements were taken back using the Sun's shadow. ${ }^{24}$

g. Profile of Prayer Room in Junior High School 2 Bukittinggi

Prayer room of junior high school 2 Bukittinggi is located on the second floor of a school building. On the first floor there is a classroom. This prayer room was built in 2005. In 2017 the prayer room walls were painted, and in 2018 the prayer roomm floor began to be tiled. Previously in the 90s the prayer room at junior high school 2 Bukittinggi was located on the first floor, but its use was only for teachers. Prayer room Junior high school 2 Bukittinggi has an area of $8 \mathrm{~m} \times 7 \mathrm{~m}$ and can accommodate 40 people during the initial construction, the

\footnotetext{
${ }^{23}$ Interview with teacher of SMAN 5 Bukittinggi, Mr Fardi, on Tuesday at $22^{\text {nd }}$ January 2019

${ }^{24}$ Interview with teacher of SMAN 5 Bukittinggi, Mr Fardi, on Tuesday at $22^{\text {nd }}$ January 2019
} 
measurement of the qibla direction at junior high school 2 Bukittinggi is determined by estimating qibla direction following the buildings around ${ }^{25}$

h. Profile of Prayer Room in Junior High School 3 Bukittinggi

Prayer room of junior high school 3 Bukittinggi is located next to the school building, on the first floor there is a classroom. This prayer room was built in 2008. Prayer room junior high school 3 has an area of $6 \mathrm{~m} \times 5 \mathrm{~m}$ and can only accommodate 35 people or two classes, so that other students pray in the midday prayer. At the time of its initial construction, Qibla direction prayer center of junior high school 3 Bukittinggi was determined by following the surrounding buildings by estimating it which was done by a handyman along with the school teacher ${ }^{26}$

i. $\quad$ Profile of Prayer Room in Junior High School 4 Bukittinggi

Prayer room of junior high school 4 Bukittinggi is located near the field in the middle of the school. junior high school 4 Bukittinnggi prayer room has a size of $7 \mathrm{M} \times 7 \mathrm{M}$ which was built in 2009. At the time of its construction, the qibla direction of junior high school 4 Bukittinggi was determined by estimating and following the surrounding buildings. ${ }^{27}$

j. Profile of Prayer Room in Junior High School 6 Bukittinggi

Prayer room in junior high school 6 Bukittinggi was held in the school complex. Prayer room of junior high school 6 Bukittinggi has an area of 8x7 M which was built in 2010. this is in accordance with the needs of the school, the construction of School prayer room was determined by qibla direction with an estimate of the direction of the $\operatorname{sun}^{28}$

k. Profile of Prayer Room in Junior high school 7 Bukittinggi

${ }^{25}$ Elvis, interview with teacher of Junior high school 2 Bukittinggi

${ }^{26}$ Joni Ahmadi, interview with principle of Junior high school 3 Bukittinggi. Prayer room Junior high school 4 Bukittinggi

${ }^{27}$ Almasri, interview with teacher of Junior high school 4 Bukittinggi

${ }^{28} \mathrm{Rifda}$, interview with one of teachers in Junior high school 6 Bukittinggi 
The prayer room in junior high school 7 Bukittinggi was built in 2010. At the beginning of its construction, junior high school 7 was located on the side of the study room. Associated with the center of the prayer room, it has been measured since the beginning of its construction as measured by the craftsman who built the prayer room. In addition, Qibla direction prayer center at junior high school 7 Bukittinggi was also measured by estimates

1. Profile of Prayer Room in Junior High School 8 Bukittinggi

The prayer room at Bukittinggi Junior high school 8 is a building in the school complex. The prayer room at junior high school 8 was established in 2014, measuring $8 \times 8$ meters, Qibla direction at the beginning of the construction was carried out using a compass. ${ }^{29}$

Table.1.

Method Determining of Qibla Direction Prayer Center in

Senior High School and Junior High Schools in Bukittinggi

\begin{tabular}{cccc}
\hline No & Name of Prayer room & Address & $\begin{array}{c}\text { Qibla } \\
\text { Determination } \\
\text { Method }\end{array}$ \\
\hline 1 & $\begin{array}{c}\text { Prayer room Al- } \\
\text { Ikram }\end{array}$ & SHS 1 Bukittinggi & Compass \\
\hline 2 & $\begin{array}{c}\text { Prayer room SMA 2 } \\
\text { Bukittinggi }\end{array}$ & SHS 2 Bukittinggi & Building \\
\hline 3 & $\begin{array}{c}\text { Prayer room } \\
\text { Baabutaubah }\end{array}$ & SHS 3 Bukittinggi & Compass \\
\hline 4 & $\begin{array}{c}\text { Prayer room } \\
\text { Mukhlisin }\end{array}$ & SHS 4 Bukittinggi & Sunset \\
\hline 5 & $\begin{array}{c}\text { Prayer room Nurul } \\
\text { Ilmi }\end{array}$ & SHS 5 Bukittinggi & Compass \\
\hline 6 & $\begin{array}{c}\text { Prayer room JHS 1 } \\
\text { Bukittinggi }\end{array}$ & JHS 1 Bukittinggi & Theodolite \\
\hline 7 & $\begin{array}{c}\text { Prayer room darul } \\
\text { Ilmi }\end{array}$ & JHS 2 Bukittinggi & Qibla Shadow \\
\hline 8 & $\begin{array}{c}\text { Prayer room } \\
\text { Mukhlisin }\end{array}$ & JHS 3 Bukittinggi & Estimation \\
\hline 9 & $\begin{array}{c}\text { Prayer room Darul } \\
\text { Hikmah }\end{array}$ & JHS 4 Bukittinggi & Building \\
\hline 10 & Prayer room JHS 6 & JHS 6 Bukittinggi & Estimation \\
\hline
\end{tabular}

\footnotetext{
${ }^{29}$ Rosneli, interview with teacher of Junior high school 8 Bukittinggi
} 


\begin{tabular}{cccc}
\hline \multicolumn{4}{c}{ Bukittinggi } \\
\hline 11 & $\begin{array}{c}\text { Prayer room Darul } \\
\text { Hikmah }\end{array}$ & JHS 7 Bukittinggi & Estimation \\
\hline 12 & $\begin{array}{c}\text { Prayer room Darul } \\
\text { Ulum }\end{array}$ & JHS 8 Bukittinggi & Compass \\
\hline
\end{tabular}

Table 2.

The Results of Qibla Direction Calibration of Prayer Rooms in Senior High School and Junior High Schools in Bukittinggi

\begin{tabular}{|c|c|c|c|c|}
\hline No & Nama of Prayer room & $\begin{array}{l}\text { Data of Qibla } \\
\text { Calibration }\end{array}$ & $\begin{array}{l}\text { Qibla } \\
\text { Angle }\end{array}$ & Deviation \\
\hline 1 & $\begin{array}{l}\text { Prayer room Al- } \\
\text { Ikram }\end{array}$ & $289^{\circ}$ & $294^{0}$ & $5^{0}$ \\
\hline 2 & $\begin{array}{c}\text { Prayer room SHS } 2 \\
\text { Bukittinggi }\end{array}$ & $289^{\circ}$ & $294^{\circ}$ & $5^{0}$ \\
\hline 3 & $\begin{array}{l}\text { Prayer room } \\
\text { Baabutaubah }\end{array}$ & $288^{\circ}$ & $294^{\circ}$ & $6^{0}$ \\
\hline 4 & $\begin{array}{l}\text { Prayer room } \\
\text { Mukhlisin }\end{array}$ & $293^{\circ}$ & $294^{0}$ & $1^{0}$ \\
\hline 5 & $\begin{array}{c}\text { Prayer room Nurul } \\
\text { Ilmi }\end{array}$ & $298^{\circ}$ & $294^{0}$ & $4^{0}$ \\
\hline 6 & $\begin{array}{c}\text { Prayer room JHS } 1 \\
\text { Bukittinggi }\end{array}$ & $294^{\circ}$ & $294^{0}$ & $0^{0}$ \\
\hline 7 & $\begin{array}{l}\text { Prayer room darul } \\
\text { Ilmi }\end{array}$ & $294^{\circ}$ & $294^{0}$ & $0^{0}$ \\
\hline 8 & $\begin{array}{c}\text { Prayer room } \\
\text { Mukhlisin }\end{array}$ & $284^{\circ}$ & $294^{0}$ & $10^{\circ}$ \\
\hline 9 & $\begin{array}{c}\text { Prayer room Darul } \\
\text { Hikmah }\end{array}$ & $280^{\circ}$ & $294^{0}$ & $14^{0}$ \\
\hline 10 & $\begin{array}{c}\text { Prayer room JHS } 6 \\
\text { Bukittinggi }\end{array}$ & $292^{\circ}$ & $294^{\circ}$ & $2^{0}$ \\
\hline 11 & $\begin{array}{c}\text { Prayer room Darul } \\
\text { Hikmah }\end{array}$ & $250^{\circ}$ & $294^{\circ}$ & $44^{\circ}$ \\
\hline 12 & $\begin{array}{c}\text { Prayer room Darul } \\
\text { Ulum }\end{array}$ & $291^{\circ}$ & $294^{\circ}$ & $3^{0}$ \\
\hline
\end{tabular}

The table above illustrates the overall sample of 12 prayer rooms in senior high schools and junior high schools throughout Bukittinggi based on their location, how to determine qibla direction and the current qibla azimuth and its qibla deviation. 
From the prayer rooms in senior high schools and junior high schools in Bukittinggi, the authors describe in several categories, namely:

1. In terms of the method of determining qibla direction

2. In terms of accuracy of qibla direction of prayer rooms in Senior high school and junior high schools in Bukittinggi which includes: first, the prayer room which is qibla direction or it's deviation is 0 . Secondly, the prayer room with deviations in qibla direction can be tolerated in tolerance facing the qibla, i.e. a maximum of two degrees. Third, small prayer rooms whose deviations deviate towards the qibla are not categorized, outside the tolerance limits facing the qibla.

Based on the findings of the qibla direction in the prayer room at junior and senior high schools in Bukittinggi related to the method of determining qibla direction, then $8 \%$ determine with theodolite, $8 \%$ with the direction of sunset, as for the qibla compass $9 \%$, with $8 \%$ qibla shadow, based on buildings around $17 \%$ and $25 \%$ using compass and $25 \%$ estimates as illustrated in the diagram below.

Figure 1.

Diagram of Method for Determining Qibla Direction of Prayer Room of Junior High School and Senior High School in Bukittinggi City

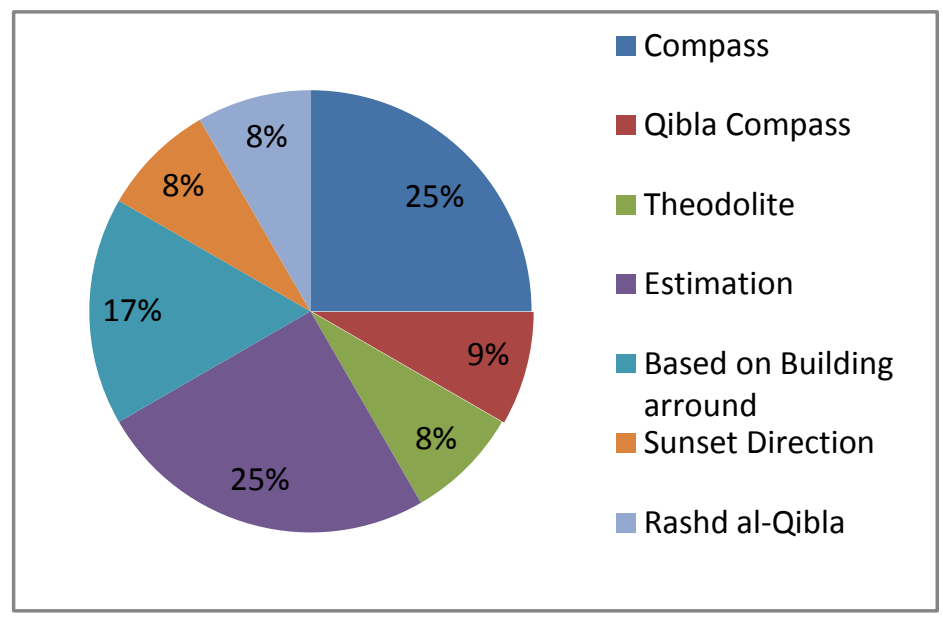


Figure 2.

Deviation direction of Qibla Direction of Prayer Room of Junior High School and Senior High School in Bukittinggi City

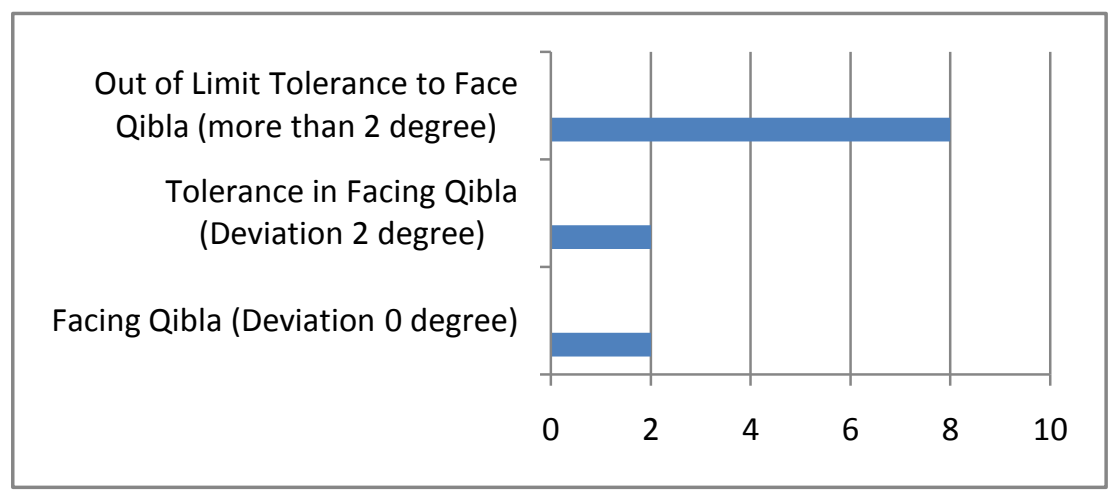

Based on the table above, there are 2 prayer rooms that heading right in qibla direction, there are 2 prayer rooms in qibla tolerance category and there are 8 prayers which it's qibla direction is deviated or outside the tolerance limit facing the Qibla. This is in accordance with the tolerance towards Qibla which is conveyed by the Hadith Baihaqi and interpreted by the understanding of astronomy in which the tolerance direction of the city of Bukittinggi. Bukittinggi coordinate is $0^{\circ} 18^{\prime} 00^{\prime \prime} \mathrm{LS}$ and $100^{\circ} 22^{\prime}$ 00" BT, then the azimuth on Google software at point $294^{\circ} 24^{\prime} 00^{\prime \prime}$. Furthermore, the azimuth of the northern boundary of Mecca is calculated from Bukittinggi with the results on Google earth $294^{\circ} 29^{\prime}$ 24". Then the azimuth of the North limit of Mecca from Bukittinggi is $0^{\circ} 5^{\prime} 24^{\prime \prime}$. That's the tolerance of Bukit Qibla head to the north. Likewise with the south, by calculating the southern limit of Makkah city azimuth is $294^{\circ} 19^{\prime} 48^{\prime}$. Then the azimuth of the southern limit of Makkah city from Bukittinggi is about $0^{\circ} 4^{\prime} 12^{\prime \prime}$ tolerance of qibla deviation.

Due to the results of calibration qibla direction of prayer room in senior high school and junior high schools in Bukittinggi, there are 8 prayer rooms that are out of tolerance and 2 prayers whose direction is at the tolerance level and only 2 prayer room which have correct qibla direction. This is closely related to the method used by the school in determining qibla direction, 3 school used usual compass, 1 school used qibla compass, 1 school considered theodolite, and 3 school decided estimates and benchmark building respectively. Moreover, 1 school with reference to the direction of the sunset and 1 other school decided to usie the sun's shadow method. 


\section{Conclusion}

Based on the description and analysis described above, the following conclusions can be drawn:

1. The method of determining qibla direction of prayer rooms in high schools and junior high schools in Bukittinggi city is various, from a simple method untill the sophisticated methods. So that the results of the measurement of the qibla direction are also influenced by the thoughts and understanding of the school related to just estimating such as following the qibla of a building, or sticking to the west and sticking to the sunset without being based on astronomical theory in determining qibla direction (taqribi), while using equipment that uses modern astronomical calculations such as using a compass, qibla compass, theodolite or calculating the occurrence of qibla shadow where the shadow of the sun at the time of the sun certain shows qibla direction.

2. From 12 prayer rooms qibla direction in high schools and junior high schools in the city of Bukittinggi there are 2 prayer rooms with the category facing Qibla, 2 prayer rooms in the category of facing the qibla boundary of toleration and 8 prayer rooms whose qibla direction is outside the tolerance limit.

\section{E. Bibliography}

Adieb, Muhammad. "Studi Komparasi Penentuan Arah Kiblat Istiwaaini Karya Slamet Hambali Dengan Theodolite.” PhD Thesis, IAIN Walisongo, 2014.

Adieb, Muhammad, and Muhammad Adieb. "Hukum Penentuan Arah Kiblat Perspektif Madzhab Syafi'i Dan Astronomis.” Inklusif (Jurnal Pengkajian Penelitian Ekonomi Dan Hukum Islam) 4, no. 1 (2019): 33-46.

Aditiani, Suci Novira, Dyah Fitriana Masithoh, and Nonoh Siti Aminah. "Penentuan Arah Kiblat Dengan Metode Segitiga Bola.” In Prosiding: Seminar Nasional Fisika Dan Pendidikan Fisika, Vol. 6, 2015.

Adiwirawan, Endro. "Relasi Spasial Antara Kegiatan Ritual Ibadah Berjamaah Dengan Arsitektur Mesjid Di Bandung Studi Kasus: Masjid Cipaganti, Masjid 
Salman, Dan Masjid Al Irsyad.” Idealog: Ide Dan Dialog Desain Indonesia 2, no. 1 (2017): 1-19.

Akbar, Reza. "Sejarah Perkembangan Ilmu Falak Dalam Peradaban India Dan Keterkaitannya Dengan Islam.” Jurnal Ilmiah Islam Futura 17 (2017): 50-72.

Alfianika, Ninit. Buku Ajar Metode Penelitian Pengajaran Bahasa Indonesia. Deepublish, 2018.

Anurkarina, Fenty Windy. "Perilaku Tokoh KH. Ahmad Dahlan Dalam Novel Sang Pencerah Karya Akmal Nasery Basral.” Kembara: Jurnal Keilmuan Bahasa, Sastra, Dan Pengajarannya 1, no. 1 (2015): 34-42.

Arikunto, Suharsimi. Metode Peneltian. Jakarta: Rineka Cipta, 2010.

Azhari, Susiknan. "Perkembangan Kajian Astronomi Islam Di Alam Melayu." Jurnal Figh 7 (2010): 167-184.

Banjary, Nur Hidayatullah el-. "Menentukan Arah Kiblat Dengan Hembusan Angin (Perspektif Fiqh Dan Sains).” Al-Marshad: Jurnal Astronomi Islam Dan Ilmu-Ilmu Berkaitan 2, no. 1 (2017).

Daulay, Mushoddik. "Akurasi Arah Kiblat Masjid Di Kecamatan Bekasi Utara (Survei Lokasi Arah Terhadap Posisi Lokasi Ka’bah).” Jurnal Geografi, Edukasi Dan Lingkungan (JGEL) 2, no. 1 (2018): 32-36.

Fauziah, Fauziah. "Validasi Arah Kiblat Masjid Dengan Bayang-Bayang Kiblat (Studi Kasus Masjid Di Kecamatan Ilir Barat Ii Kota Palembang).” Nurani: Jurnal Kajian Syari'ah Dan Masyarakat 18, no. 2 (2018): 99-114.

Hamdani, Fahmi Fatwa Rosyadi Satria, Ramdan Fawzi, and Rifki Gapuraning Syahid. "Pendampingan Pengukuran Arah Kiblat Masjid Di Rancabango Garut." Dimas: Jurnal Pemikiran Agama Untuk Pemberdayaan 18, no. 1 (2018): $19-34$.

Hosen, Hosen, and Ghafiruddin Ghafiruddin. "Akurasi Arah Kiblat Masjid Di Wilayah Kecamatan Pademawu Kabupaten Pamekasan Dengan Metode Mizwala Qibla Finder.” Al-Ihkam: Jurnal Hukum Eg Pranata Sosial 13, no. 2 (2018): 364-381. 
Izzuddin, Ahmad. Kajian Terhadap Metode-Metode Penentuan Arah Kiblat Dan Akurasinya. Kementerian Agama Republik Indonesia, 2012.

Khazin, Muhyiddin. "Cara Mudah Mengukur Arah Kiblat, Cet. II." Yogyakarta: Buana Pustaka, 2006.

Mujab, Sayful. "Qiblat Tiap Saat Sebagai Jembatan Penentu Arah Qiblat.” YUDISIA: Jurnal Pemikiran Hukum Dan Hukum Islam 6, no. 1 (2016): 160-180.

Nafi, Agus Yusrun. "Verifikasi Fatwa MUI Nomor 03 Tahun 2010 Tentang Arah Kiblat.” Mahkamah: Jurnal Kajian Hukum Islam 9, no. 1 (2016).

Nurkhanif, Muhammad. "Problematika Sosio-Historis Arah Kiblat Masjid 'Wali' Baiturrahim Gambiran Kabupaten Pati Jawa Tengah.” Al Qodiri: Jurnal Pendidikan, Sosial Dan Keagamaan 15, no. 2 (2018): 32-58.

Raharto, Moedji, and Dede Jaenal Arifin. "Telaah Penentuan Arah Kiblat Dengan Perhitungan Trigonometri Bola Dan Bayang-Bayang Gnomon Oleh Matahari.” Jurnal Fisika Himpunan Fisika Indonesia 11, no. 1 (2011): 23-29.

Sudibyo, Muh. "Sang Nabipun Berputar: Arah Kiblat Dan Tatacara Pengukurannya." Solo: Tinta Media, 2011. 